\title{
Anthropometry and Body Composition of Adolescents in Macedonia
}

\author{
Antropometría y Composición Corporal de Adolescentes en Macedonia
}

Nazim Myrtaj'; Arben Maliqii; Seryozha Gontarev²; Ruzdija Kalac²; Georgi Georgiev² \& Biljana Bojadzieva Stojanoska

MYRTAJ, N.; MALIQI, A.; GONTAREV, S.; KALAC, R.; GEORGIEV, G. \& STOJANOSKA, B. B. Anthropometry and body composition of adolescents in Macedonia. Int. J. Morphol., 36(4):1398-1406, 2018.

SUMMARY: The aim of this research was to determine the level of adiposity and obesity among Macedonian adolescents and to compare the results with previous studies conducted in this population, as well as those conducted in other populations. The sample included 2390 adolescents from four urban different regions of R. Macedonia aged between 11 to 18 years; 1238 males and 1152 females. Weight, height, waist, and hip circumference (WC, HC) as well as triceps, calf, subscapular, and suprailiac skinfold thickness (SFT) were measured. Body mass index (BMI), waist-to-hip ratio (WHR), waist-to-height ratio (WHtR), subscapular/triceps skinfold ratio (STR), and percentage body fat were computed. The prevalence of overweight and obesity defined by the IOTF children growth reference were calculated and age-dependent and gender-specific smoothed percentile curves for BMI and ROC curves were generated. The boys have statistically significantly higher values of WC, WHR and WHtR in all adult categories (except WHtR at 18 years old), greater body weight at the age of 12 to 18 , and body weight 13 to 18 years ( $\mathrm{p}<0.001)$. Weight, height and BMI are increasing with age in both, boys and girls, and decreases in girls. The level of adiposity of Macedonian adolescents has increased over the past 20 years and has reached the level of developed countries that face an obesity epidemic.

KEY WORDS: Macedonian adolescents; Skinfold thickness; Waist circumference; Waist-to-height ratio; Waist-to-hip ratio.

\section{INTRODUCTION}

The increased adiposity in children and adolescents becomes a global health problem both in development and the developing countries (Li et al., 2006; Senbanjo et al., 2013). In 2010, around 43 million children worldwide were considered obese - 35 million in developing countries (de Onis et al., 2010). The global prevalence of overweight and obesity in children has increased from $4.2 \% 1990$ to $6.7 \%$ in 2010 and is expected to reach $9.1 \%$ until 2020 (de Onis et al., 2010). If obesity occurs, especially in adolescence, it remains in adulthood, which affects the overall health of the individual by increasing the risk of developing diabetes mellitus, hypertension, coronary artery disease and metabolic syndrome (Lee et al., 2012). Furthermore, the increased level of adiposity is associated with depression suggests that psychological morbidity is also an important consequence (Murabito et al., 2013). Therefore, it is necessary to monitor the body parameters in children and adolescents in order to prevent the accumulation of excess body fat and its associated morbidities. Body fat can be measured through various tools and indicators. These indicators can be used to describe several types of obesity, but they also have different limitations on the sensitivity and reliability of the data obtained. Therefore, care must be taken in selecting adequate tools to be used and measure the obesity of the population level. The most commonly used tool is the Body Mass Index (BMI) used by the World Health Organization as a standard for recording obesity and constructing growth curves in children and adolescents (de Onis et al., 2007). Despite the many advantages of this index, the BMI has some limitations. It does not take into account many factors such as the percentage of muscle tissue (Moreno et al., 2003), bone density, different proportions of fat, bone tissue water in the body. Also, a very anthropometric measure for assessing central obesity in children and adolescents is the waist circumference (WC). Conversely, the waist to hip ratio (WHR) is not an accurate indicator of abdominal obesity in youth because of the weak correlation with central adiposity (Taylor et al., 2000). Skin folds measurements (SFT) can be

${ }^{1}$ Faculty of Physical Culture and Sports, AAB College, Prishtinë, Kosovo.

${ }^{2}$ Faculty of Physical Education, Sport, and Health, Ss. Cyril and Methodius University, Skopje, Macedonia.

${ }^{3}$ Institute of Anatomy, Ss. Cyril and Methodius University, Skopje, Macedonia. 
used as specific indexes for estimating obesity due to their high sensitivity. Because of the latter, it is recommended to monitor obesity in children and adolescents (Hughes et al., 1997) and to allow an indirect assessment of total body fat that can be used as a screening tool. According to Noyens et al. (2007), the best indicator of obesity in body is subcapular SFT, and in girls biceps SFT. In this study, the two measures were better predictors than the sum of the four SFTs. In addition, obesity can be effectively evaluated by using the ratio of subscapular and triceps - SFT (Moreno et al., 2007). Therefore, obesity in adulthood is better predicted by adolescent skinfold thickness than by adolescent BMI. It is therefore important to check how other indexes such as skinfold thickness, might be applied to the Macedonian population.

The purpose of this study was to predict the level of adiposity and obesity in Macedonian adolescents. The collected data can be used to document and describe the changes in obesity in children and adolescents in Macedonia. Monitoring the anthropometric changes at the population level can be crucial in prevention of negative health outcomes related to adiposity. The regular anthropometric estimates of the population can provide the key information that will allow health institutions to determine the points at which they should begin mounting interventions.

\section{MATERIAL AND METHOD}

Participants. The sample included 2390 adolescents from four urban different regions of R. Macedonia aged between 11 to 18 years; 1238 males and 1152 females. Participants from selected schools and classes were informed about the objective of the study and their parents signed the informed consent for participation in the research. All adolescents were healthy at the time of this study. In order to avoid errors in the selection of the sample, volunteer students were not included.

In the sample entered all students for whom the parents gave their consent to participate in the project and were psycho-physically healthy and regularly attended classes for physical and health education. The respondents were treated in accordance with the Helsinki Declaration.

The measurement was realized in March, April and May 2016, in standard school conditions at regular classes in physical and health education. Measurement was realized by experts in the field of kinesiology and medicine, who were trained for measuring certain anthropometric measures.
Anthropometry measurement. For evaluation anthropometric variables were selected and measured according to the International Biological Program (IBP): body height, body weight, four skinfolds (triceps, subscapular, supraspinale and calf), and two circumferences (waist and hip). BMI was calculated as a ratio of body weight and height to square $\left(\mathrm{kg} / \mathrm{m}^{2}\right)$, WHR was calculated as a ratio of the circumference of the waist and hips and WHtR to the ratio of the circumference of the waist and height \%BF was calculated using the equations of Slaughter et al. (1988) - from the triceps and subscapular sites (SL1); and triceps and calf sites (SL2). The following standard anthropometric instruments were used: for measuring body height. Anthropometer by Martin, with $1 \mathrm{~mm}$ reading accuracy; decimal weight scale; "John Bull" caliper square for determination of skin-folds with pressure of $10 \mathrm{~g} / \mathrm{cm}^{2}$ and precision of $0.1 \mathrm{~mm}$; elastic band, also with $1 \mathrm{~mm}$ reading accuracy, for measuring circumferences; and caliper square for measuring of diameters with reading precision of $1 \mathrm{~mm}$ and weight scale for measuring body weight. Anthropometric measurements were made during school hours, not interrupting the lessons. Subjects were standing, facing ahead, and body height was measured as maximum distance from the floor to the highest point on the head. Shoes were off, both feet together, and arms at the sides. Heels, buttocks and upper back were in contact with the wall. Body height measurement can vary throughout the day, usually being higher in the morning, so to ensure reliability we measured height at the same time of the day.

Statistical analysis. Data was presented as the mean and standard deviation (SD). Sex differences in anthropometric characteristics were analyzed by one-way analysis of variance (ANOVA). Correlation coefficients were calculated to measure statistical dependence between anthropometric indices and age. The relation between WHtR, four skinfolds (triceps, subscapular, supraspinale and calf), sum of four skinfolds, body fat $\%$ and overweightobesity as defined by the IOTF was investigated with ROC analysis. The discriminating power was expressed as area under the curve (AUC). Smoothed age-and sex-specific table and graph percentiles were constructed for BMI by the LMS method. This estimates the measurement centiles in terms of three age-sex-specific cubic spline curves: the L curve (Box-Cox power to remove skewness), M curve (median) and S curve (coefficient of variation). For the construction of the percentile curves, data were imported into the Lms Chart Maker software (v. 2.3; by Tim Cole and Huiqi Pan) and the L, M and S curves estimated. Except for the LMS method calculations, we used SPSS v. 22.0 software for Windows (SPSS, Chicago, Illinois, USA). 


\section{RESULTS}

The research was realized on a sample of 2390 adolescents at the age of 11 to 18 years. The average age of the sample $( \pm \mathrm{sd})$ was $14,4( \pm 2,27)$ years. Descriptive statistical parameters for varaiables $\mathrm{BW}, \mathrm{Ht}, \mathrm{BMI}, \mathrm{WC}$, HC, WHR and WHtR, in terms of sex and age, are shown in Table I. The weight, height and BMI increase with age for boys (respectively: $r=.740 ; r=.604 ; r=.331$. All $p<0.001$ and for girls (respectively: $r=.468 ; r=.435 ; r=.286$. All $\mathrm{p}<0.001)$. WHR remains constant for boys with age, and decreases for girls $(\mathrm{r}=.111, \mathrm{p}<0.001)$. WHtR NS remain constant with age for boys and girls. Boys have statistically significantly higher values of WC, WHR, WHtR in all age categories (except WHtR at 18 years old), a greater body weight at the age of 12 to 18 years and a body height of 13 to 18 years $(\mathrm{p}<0.001)$. Also, boys have statistically significant BMI values at the age of 15,16 and 18 years $(\mathrm{p}<0.01)$.

Skinfolds measurements values and $\mathrm{BF} \%$ are presented in Table II. Values of triceps, subscapular, calf
SFT as well as the percentage of fat tissue (BF\%) decreases with age for boys. On the other hand, the values of Subscapular, Supraspinale SFT, sum of 4 skinfolds and $\% \mathrm{BF}$ increases with age in girls. Girls have statistically significantly higher values of triceps, calf SFT and sum of 4 skinfolds at the age of 13 to 18 years and higher values of subscapular supraspinale SFT at the age of 13 to 17 years. Also, girls have higher values of $\% \mathrm{BF}$ in all age categories.

In Table III and Figure 1 the smoothed sex and agespecific percentile values are shown at the $5^{\text {rd }}, 10^{\text {th }}, 25^{\text {th }}$, $50^{\text {th }}, 75^{\text {th }}, 75^{\text {th }}, 85^{\text {th }}$ and $95^{\text {th }}$ percentiles, which were developed and smoothed by the LMS method. According to the IOTF study BMI cut-off norms there were 362 (28.3 $\%$ ) males and 207 (17.9\%) females considered overweight (including obesity), which represents $23.8 \%$ of all participants. Obese status was determined in $89(7.2 \%)$ boys and $28(2.4 \%)$ girls. These values are presented in the Table IV.

Table I. Mean values $( \pm \mathrm{SD})$ of body measurements in male and female Macedonian adolescents aged 11-18.

\begin{tabular}{|c|c|c|c|c|c|c|c|c|c|c|c|c|c|c|c|}
\hline $\begin{array}{c}\text { Age } \\
(\mathrm{y}) \\
\text { Boys }\end{array}$ & Number & \multicolumn{2}{|c|}{ BW (kg) } & \multicolumn{2}{|c|}{$\mathrm{Ht}(\mathrm{cm})$} & \multicolumn{2}{|c|}{ BMI $(\mathrm{kg} / \mathrm{m} 2)$} & \multicolumn{2}{|c|}{$\mathrm{WC}(\mathrm{cm})$} & \multicolumn{2}{|c|}{$\mathrm{HC}(\mathrm{cm})$} & \multicolumn{2}{|c|}{ WHR } & \multicolumn{2}{|c|}{ WHtR } \\
\hline 11 & 167 & 44.02 & 11.19 & 151.13 & 7.31 & 19.08 & 3.65 & 69.01 & 9.68 & 82.32 & 8.71 & 0.84 & 0.05 & 0.46 & 0.06 \\
\hline 12 & 150 & 51.62 & 14.43 & 158.23 & 9.83 & 20.34 & 4.14 & 71.79 & 10.97 & 87.28 & 10.69 & 0.82 & 0.06 & 0.45 & 0.06 \\
\hline 13 & 140 & 54.69 & 13.72 & 164.46 & 10.35 & 20.00 & 3.55 & 71.26 & 9.38 & 88.16 & 8.75 & 0.81 & 0.06 & 0.43 & 0.05 \\
\hline 14 & 159 & 62.20 & 14.69 & 170.02 & 8.11 & 21.34 & 4.11 & 75.45 & 11.37 & 92.55 & 9.76 & 0.81 & 0.07 & 0.44 & 0.06 \\
\hline 15 & 164 & 67.66 & 13.63 & 173.63 & 7.14 & 22.41 & 4.24 & 78.04 & 11.22 & 94.01 & 9.53 & 0.83 & 0.06 & 0.45 & 0.06 \\
\hline 16 & 161 & 69.26 & 11.81 & 175.52 & 6.31 & 22.50 & 3.91 & 77.94 & 9.35 & 92.96 & 8.39 & 0.84 & 0.06 & 0.44 & 0.06 \\
\hline 17 & 160 & 71.74 & 13.72 & 177.89 & 7.08 & 22.62 & 3.87 & 79.49 & 11.00 & 94.90 & 8.10 & 0.84 & 0.07 & 0.45 & 0.06 \\
\hline 18 & 137 & 75.12 & 11.56 & 179.24 & 7.04 & 23.35 & 3.14 & 79.93 & 8.50 & 97.54 & 6.74 & 0.81 & 0.09 & 0.45 & 0.05 \\
\hline Total & 1238 & 62.04 & 13.09 & 168.76 & 7.89 & 21.45 & 3.83 & 75.36 & 10.18 & 91.22 & 8.83 & 0.82 & 0.06 & 0.45 & 0.06 \\
\hline \multicolumn{16}{|l|}{ Girls } \\
\hline 11 & 148 & 42.70 & 10.87 & 151.58 & 7.09 & 18.41 & 3.54 & 64.23 & 8.55 & 83.26 & 9.48 & 0.77 & 0.05 & 0.42 & 0.05 \\
\hline 12 & 151 & 48.72 & 9.67 & 157.24 & 7.50 & 19.64 & 3.38 & 67.41 & 7.50 & 88.45 & 7.83 & 0.76 & 0.05 & 0.43 & 0.05 \\
\hline 13 & 146 & 51.69 & 9.19 & 160.78 & 6.54 & 19.94 & 3.04 & 67.80 & 7.91 & 90.75 & 7.61 & 0.75 & 0.06 & 0.42 & 0.05 \\
\hline 14 & 146 & 56.13 & 9.24 & 163.14 & 6.54 & 21.07 & 3.08 & 69.94 & 7.63 & 94.38 & 7.06 & 0.74 & 0.05 & 0.43 & 0.05 \\
\hline 15 & 148 & 56.21 & 9.21 & 163.08 & 5.96 & 21.12 & 3.23 & 70.69 & 7.75 & 93.46 & 7.45 & 0.75 & 0.08 & 0.43 & 0.05 \\
\hline 16 & 150 & 56.29 & 8.21 & 163.33 & 6.34 & 21.09 & 2.71 & 70.15 & 7.61 & 93.28 & 6.50 & 0.75 & 0.06 & 0.43 & 0.05 \\
\hline 17 & 131 & 58.66 & 9.32 & 163.45 & 5.53 & 21.93 & 3.16 & 71.98 & 8.60 & 94.51 & 7.20 & 0.76 & 0.07 & 0.44 & 0.05 \\
\hline 18 & 132 & 57.52 & 7.84 & 164.78 & 6.02 & 21.19 & 2.76 & 69.48 & 6.03 & 94.45 & 5.88 & 0.74 & 0.04 & 0.42 & 0.04 \\
\hline Total & 1152 & 53.49 & 9.19 & 160.92 & 6.44 & 20.55 & 3.11 & 68.96 & 7.70 & 91.57 & 7.38 & 0.75 & 0.06 & 0.43 & 0.05 \\
\hline
\end{tabular}




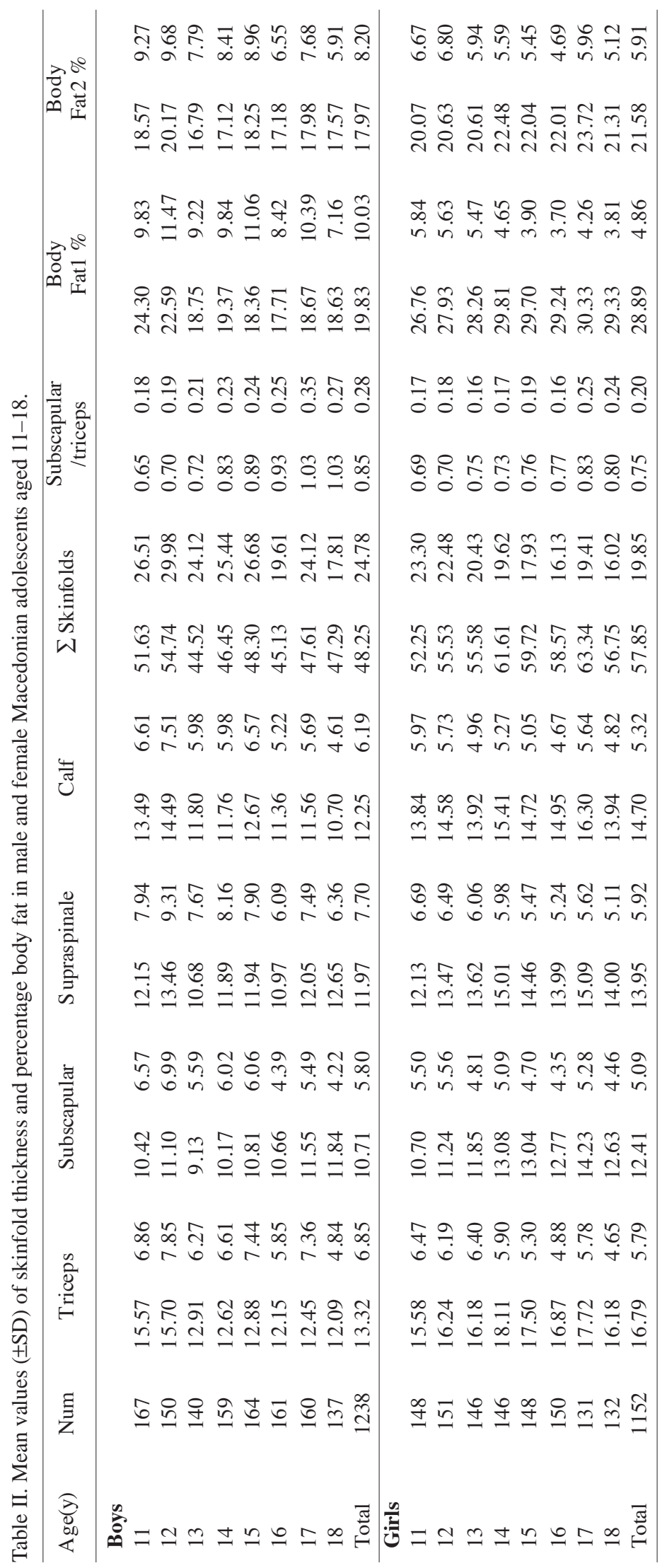

The ROC curves of measured and computed indicators for predicting obesity on the basis of IOTF study BMI cut-offs are shown in Figure 2 and Table V. ROC analysis show that the measure sum of 4 skinfolds for male respondents have the greatest discriminating power in predicting IOTF obesity (area under the curve [AUC]: 0.941 $\pm 0.007 ; 95 \%$ CI 0.927-0.955), followed by the supraspinale SFT (AUC: $0.936 \pm 0.007 ; 95 \%$ CI $0.922-0.955$ ) and WHtR (AUC: 0.929 \pm 0.009 ; $95 \%$ CI 0.912-0.946). For girls, the greatest discriminatory power is the measure sum of 4 skinfolds (AUC: $0.907 \pm 0.010 ; 95$ $\%$ CI 0.887-0.927), followed by the WHtR (AUC: $0.898 \pm 0.012 ; 95 \%$ CI $0.875-0.927$ ) and then the supraspinale SFT (AUC: 0.879 $\pm 0.012 ; 95 \%$ CI $0.855-0.903$ ) values were the best predictors of obesity.

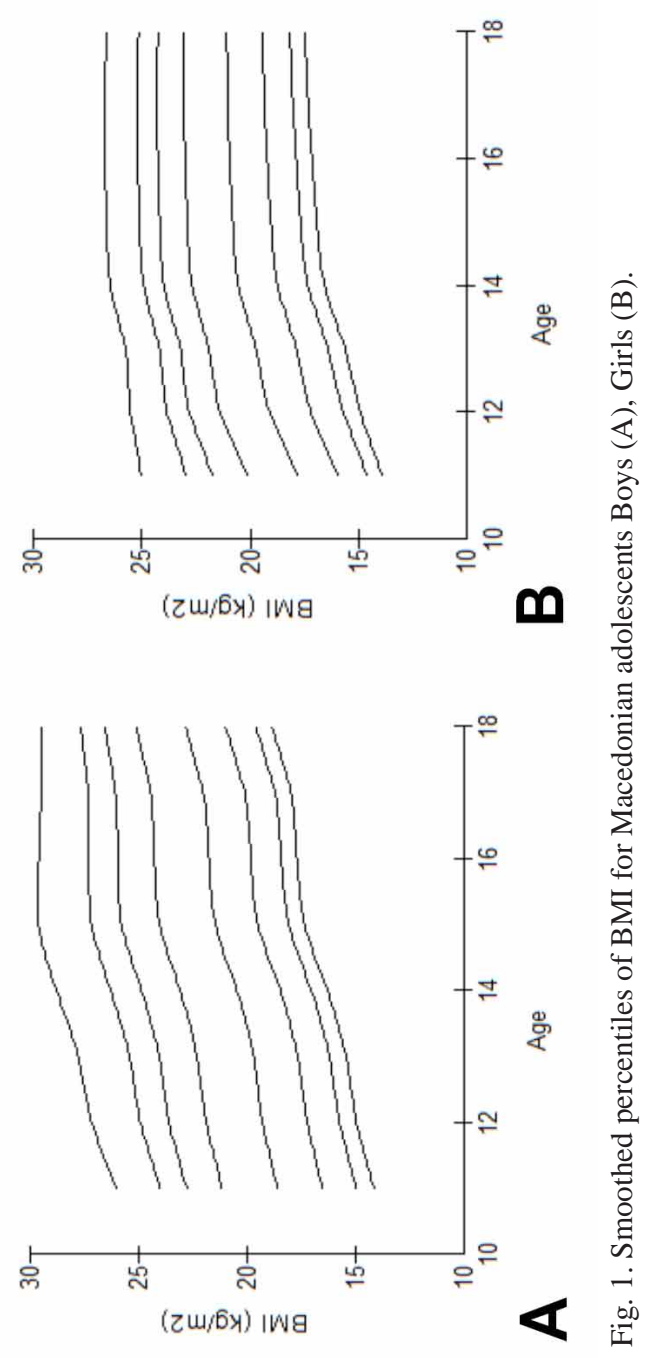


Table III. Percentile values of body mass index (BMI) in male and female Macedonian adolescents aged $11-18$ for the $85^{\text {th }}$ and $95^{\text {th }}$ percentiles.

\begin{tabular}{|c|c|c|c|c|c|c|c|c|c|c|c|}
\hline \multicolumn{11}{|l|}{ Age (yr) } & \multirow[b]{2}{*}{$95^{\text {th }}$} \\
\hline & $\mathrm{L}$ & M & $S$ & $5^{\text {th }}$ & 10th & $25^{\text {th }}$ & $50^{\text {th }}$ & $75^{\text {th }}$ & $85^{\text {th }}$ & 90th & \\
\hline \multicolumn{12}{|l|}{ Boys } \\
\hline 11 & -0.70 & 18.61 & 0.18 & 14.17 & 14.98 & 16.53 & 18.61 & 21.17 & 22.81 & 24.04 & 26.09 \\
\hline 12 & -0.99 & 19.32 & 0.18 & 14.96 & 15.75 & 17.26 & 19.32 & 21.93 & 23.64 & 24.97 & 27.22 \\
\hline 13 & -1.19 & 19.70 & 0.17 & 15.44 & 16.20 & 17.67 & 19.70 & 22.32 & 24.07 & 25.43 & 27.81 \\
\hline 14 & -1.43 & 20.48 & 0.16 & 16.30 & 17.04 & 18.48 & 20.48 & 23.11 & 24.89 & 26.31 & 28.82 \\
\hline 15 & -1.57 & 21.49 & 0.15 & 17.37 & 18.10 & 19.52 & 21.49 & 24.07 & 25.82 & 27.21 & 29.67 \\
\hline 16 & -1.55 & 21.79 & 0.15 & 17.71 & 18.44 & 19.85 & 21.79 & 24.29 & 25.98 & 27.31 & 29.63 \\
\hline 17 & -1.50 & 22.02 & 0.14 & 17.98 & 18.71 & 20.11 & 22.02 & 24.47 & 26.09 & 27.35 & 29.53 \\
\hline 18 & -1.28 & 22.87 & 0.13 & 18.86 & 19.60 & 21.01 & 22.87 & 25.15 & 26.60 & 27.70 & 29.53 \\
\hline $\begin{array}{l}\text { Girls } \\
11\end{array}$ & -1.10 & 17.83 & 0.17 & 13.93 & 14.63 & 15.98 & 17.83 & 20.19 & 21.76 & 22.97 & 25.05 \\
\hline 12 & -0.57 & 19.14 & 0.16 & 14.94 & 15.73 & 17.21 & 19.14 & 21.42 & 22.82 & 23.86 & 25.54 \\
\hline 13 & -0.53 & 19.73 & 0.15 & 15.63 & 16.42 & 17.87 & 19.73 & 21.91 & 23.23 & 24.19 & 25.74 \\
\hline 14 & -0.69 & 20.56 & 0.14 & 16.59 & 17.35 & 18.76 & 20.56 & 22.69 & 23.98 & 24.93 & 26.46 \\
\hline 15 & -0.80 & 20.81 & 0.14 & 16.94 & 17.68 & 19.05 & 20.81 & 22.89 & 24.17 & 25.11 & 26.63 \\
\hline 16 & -0.88 & 202.95 & 0.13 & 17.16 & 17.88 & 19.22 & 20.95 & 23.00 & 24.26 & 25.19 & 26.70 \\
\hline 17 & -0.97 & 21.06 & 0.13 & 17.35 & 18.06 & 19.37 & 21.06 & 23.07 & 24.31 & 25.23 & 26.73 \\
\hline 18 & -1.07 & 21.08 & 0.13 & 17.49 & 18.17 & 19.44 & 21.08 & 23.04 & 24.26 & 25.16 & 26.63 \\
\hline
\end{tabular}

Table IV. The prevalence of overweight and obesity in Macedonian boys and girls aged 11-18

\begin{tabular}{lcccc}
\hline & $\mathrm{n}$ & Normal & Overweight & Obese \\
\hline Boys & 1238 & 876 & 273 & 89 \\
& & $70,8 \%$ & $22,1 \%$ & $7,2 \%$ \\
Girls & 1152 & 945 & 179 & 28 \\
& & $82,0 \%$ & $15,5 \%$ & $2,4 \%$ \\
\multirow{2}{*}{ Total } & 2390 & 1821 & 452 & 117 \\
& & $76,2 \%$ & $18,9 \%$ & $4,9 \%$ \\
$\mathrm{c}^{2}=50,94 ; \mathrm{p}<0.001$ & & & \\
\hline
\end{tabular}

Table V. Cut-Points of anthropometric variables in Adolescents According to Sex.

\begin{tabular}{|c|c|c|c|c|c|}
\hline & AUC & $(95 \% \mathrm{CI})$ & Cut-point & $\begin{array}{l}\text { Sensitivity } \\
(95 \% \mathrm{CI})\end{array}$ & Specificity \\
\hline \multicolumn{6}{|l|}{ Male } \\
\hline Triceps & 0,893 & 0,874 to 0,909 & $>16,8$ & 66,85 & 92,92 \\
\hline Subscapular & 0,928 & 0,912 to 0,941 & $>12,0$ & 77,07 & 92,58 \\
\hline Supraspinale & 0,936 & 0,921 to 0,949 & $>14,2$ & 81,22 & 90,06 \\
\hline Calf & 0,894 & 0,875 to 0,910 & $>15,8$ & 65,19 & 93,84 \\
\hline$\sum$ Skinfolds & 0,941 & 0,926 to 0,953 & $>56,4$ & 81,49 & 92,81 \\
\hline Body Fat1 \% & 0,921 & 0,904 to 0,935 & $>24,5$ & 70,99 & 93,38 \\
\hline Body Fat $2 \%$ & 0,935 & 0,920 to 0,948 & $>20,3$ & 79,28 & 93,72 \\
\hline WHtR & 0,929 & 0,913 to 0,943 & $>0,50$ & 78,67 & 92,12 \\
\hline WC & 0,906 & 0,888 to 0,922 & $>81,0$ & 69,25 & 93,38 \\
\hline \multicolumn{6}{|l|}{ Female } \\
\hline Triceps & 0,866 & 0,845 to 0,885 & $>25,4$ & 32,37 & 97,35 \\
\hline Subscapular & 0,865 & 0,843 to 0,884 & $>17,8$ & 51,21 & 94,39 \\
\hline Su praspinale & 0,879 & 0,859 to 0,897 & $>20,2$ & 49,28 & 95,13 \\
\hline Calf & 0,858 & 0,836 to 0,877 & $>23,4$ & 26,09 & 98,20 \\
\hline$\sum$ Skinfolds & 0,907 & 0,889 to 0,923 & $>82,4$ & 47,83 & 97,14 \\
\hline Body Fat1 \% & 0,851 & 0,828 to 0,870 & $>33,7$ & 38,65 & 97,88 \\
\hline Body Fat $2 \%$ & 0,888 & 0,868 to 0,905 & $>28,2$ & 54,11 & 95,45 \\
\hline WHtR & 0,898 & 0,879 to 0,915 & $>0,5$ & 64,25 & 92,69 \\
\hline WC & 0,866 & 0,845 to 0,885 & $>81,0$ & 29,95 & 98,62 \\
\hline
\end{tabular}



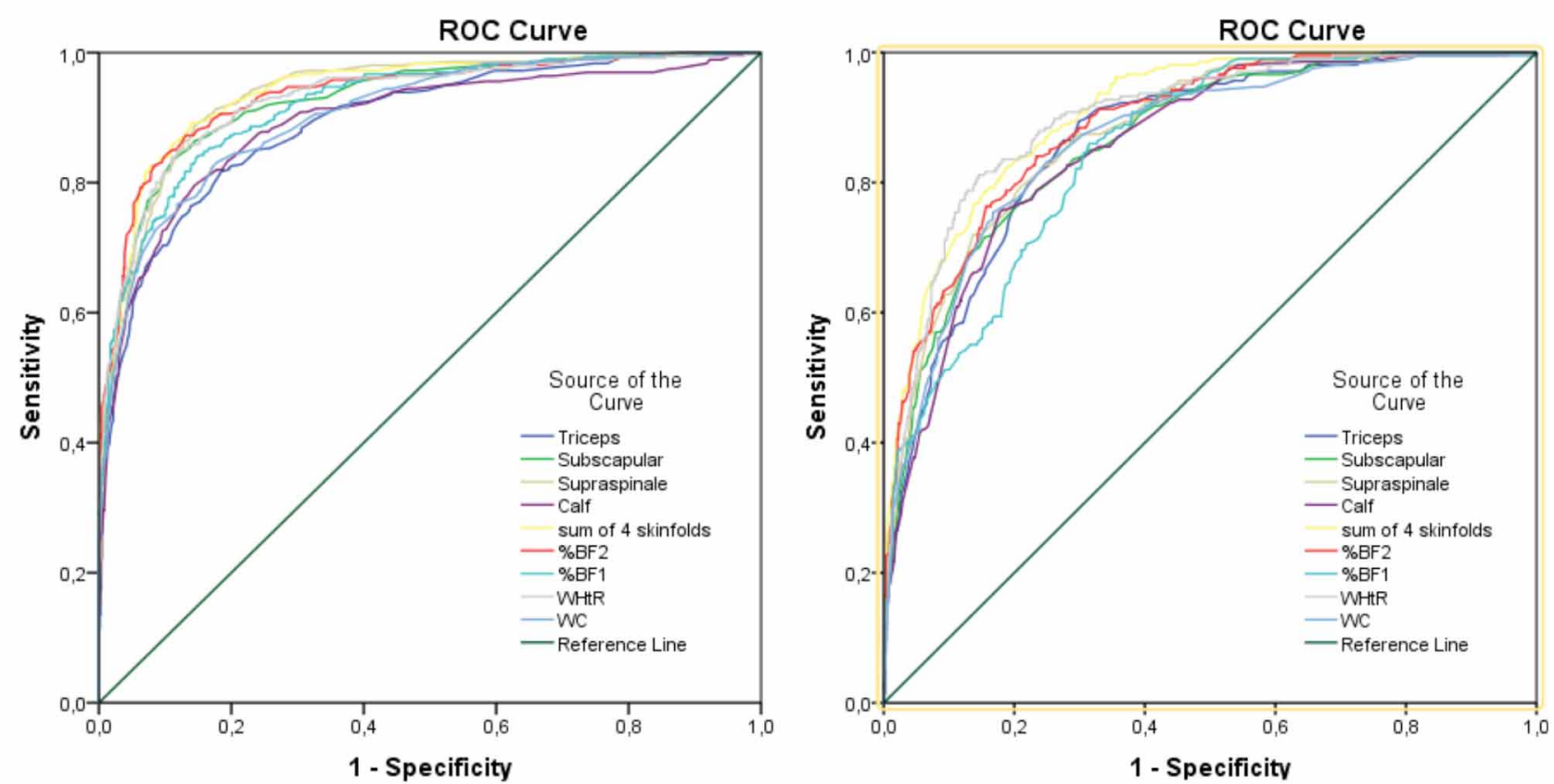

Fig. 2. ROC curves (boys - A, girls - B) for predicting obesity according to the growth reference figure obtained for waist-to-height ratio (WHtR), percentage body fat (\%BF), calf, triceps, subscapular, suprailiac skinfolds and their sum.

\section{DISCUSSION}

The aim of this study was to determine the level of adiposity and obesity among Macedonian adolescents using several anthropometric measures and to compare the obtained results with the results obtained from adolescents from different geographical regions and ethnic backgrounds. BMI cut-offs from the IOTF study were used to establish overweight and obesity status. Comparing our results with global collected data over the past 17 years has shown many differences in the measured parameters. The BMI values of the Macedonian boys in all age groups were higher than in the boys from Nigeria (Senbanjo et al.), Bahrain (Gharib \& Shah, 2009), Bolivia (Baya Botti et al., 2009), Hong Kong except at the age of 14 years (Sung et al., 2008). The Macedonian boys showed higher values in BMI than German boys at the age of 14 to 18 years, the Bulgarian (Galcheva et al., 2009) and Koreans at the age of 15 to 18 years and lower in relation to the Cyprus (Savva et al., 2001) and Kuwait boys (Department of Food and Nutrition Administration, 2005) in all age categories. In girls, the BMI values were lower than girls from Bahrain, Bolivia and Kuwait in all age categories, and lower than the Bulgarian adolescents at the age of 11 to 15 years, German at the age of 11,13 and 16 years. Macedonian girls showed higher BMI values in all age categories than adolescents from Hong Kong, Nigeria and Norway (except at the age of 16 and 18 years). In most cases these differences were small and dependent on age and sex.
Furthermore, the result of the research indicate that $22.1 \%$ of boys and $15.5 \%$ of girls have overweight (according to the BMI classification), which represents 18.9 $\%$ of the total number of adolescents. On the other hand 7.2 $\%$ of boys and $2.4 \%$ of girls are classified as obese (BMI>p95), which represents $4.9 \%$ of the total number of adolescents. The cumulative percentage of obesity and overweight status was $29.2 \%$ for boys and $18.0 \%$ for girls (23.8\% for all adolescents). Because of the different methodology used to define overweight and obesity in adolescents, caution should be exercised when comparing data from different studies. Therefore, the comparison was limited to those studies using a similar methodology as in this study. Using the cut-off points recommended by IOTF, Lobstein \& Frelut (2003) present the percentage of overweight (overweight includes obese) adolescents aged around 11-18 years in various countries: Slovakia (8\%), Russia (9\%), Czech Republic (9\%), Netherlands (11\%), Poland (12\%), Germany (13\%), Denmark (17\%), Bulgaria (17\%), Croatia and Zagreb (20\%), Great Britain (21\%), Spain (21\%), Greece and Thessaloniki (22\%) and Cyprus $(23 \%)$. Compared to the above countries Macedonian adolescents in this study seem to fall near the middle-high of the 10-34\% range, presented (23.8\%). Comparison of the results of this study with those of the Arab counties (Musaiger et al., 2016) reveals a very high 
prevalence of overweight as shown by the high combined percentage of overweight and obese individuals in Kuwait $(60.4 \% ; 41.4 \%)$, United Arab Emirates, the city Sharjah $(38.9 \% ; 20.2 \%)$ and Jordan, Haman $(31.8 \% ; 22.1 \%)$ both for boys and girls. Our result comparison \%BF with the German ones (Haas et al., 2011) indicate a higher percentage of fatty tissue among Macedonian adolescents (12-18 years).

Also, the results of our study suggests that boys tend to have a greater prevalence of obesity compared to girls ( $29.2 \%$ for boys and $18.0 \%$ for girls). This is probably due to the fact that in this adult period girls are more concerned about their appearance and more attentive to the diet. On the other hand, boys are less engaged in spontaneous physical activities and spend most of their free time in sedentary activities (compared work, watching television, etc.).

The results of the study indicate that the highest percentage of overweight including obesity have boys at the age of 12 years $(34.0 \%)$ and girls at the age of 14 years $(24.0 \%)$, while the smallest percentage has 13 -year-old boys $(20.7 \%)$ and 16 -year-old girls $(10.0 \%)$. Over $24.0 \%$ of the respondents have sum of 4 skinfolds greater than cut-off values. This high percent of body fat is associated with an increased risk of acute and chronic diseases, particularly osteoarthritis, increased blood pressure, diabetes mellitus and cardiovascular disease, which can lead to poor quality of life, increased personal and financial burden for the individual, society and shortening the life span (Dugan, 2008). The determined differences in the degree of obesity may be due to the ethnic and genetic differences between the surveyed populations, the geographical and socio-economic conditions, the variations in the composition of the food, the forms of food intake and physical activity.

Because there are significant differences in the four most commonly used anatomical parts for WC measures (de Onis et al., 2010), it is difficult to make international comparisons of $\mathrm{WC}$, and to assess the prevalence of metabolic syndrome. For example, the prevalence of metabolic syndrome as predicted by WC measurements differed by $3 \%$ among the measurement sites in men between the umbilicus and minimal waist, whereas in women, the prevalence ranged from $15.1 \%$ (umbilicus) to $14.4 \%$ (iliac crest), $14.1 \%$ (midpoint between iliac crest and the lowest rib), and $13.1 \%$ (minimal waist) (Go?ab $\&$ Chrzanowska, 2002). Considering the predictive role of WC in the IDF criteria for metabolic syndrome, and the differences in mean WC among different ethnicities, (Nooyens et al., 2007) international standardization of the protocol for measurement of WC is warranted. From 11 to 18 years in 90th percentile, WC for Macedonian adolescents ranges from 80.8 to $90.2 \mathrm{~cm}$ for boys and from 73.4 to 78.5 $\mathrm{cm}$ in girls. In Hong Kong Chinese from 74.0 to $81.6 \mathrm{~cm}$ in boys and from 68.4 to $72.6 \mathrm{~cm}$ in girls, in German adolescents from 80.4 to $91.8 \mathrm{~cm}$ in boys and from 79.4 to $85.4 \mathrm{~cm}$ in girls, in Norwegian adolescents from 71.3 to $86.7 \mathrm{~cm}$ in boys and from 69.3 to $76.8 \mathrm{~cm}$ in girls, in Poland adolescents from 75.5 to $86.5 \mathrm{~cm}$ in boys and from 71.9 to $78.8 \mathrm{~cm}$ in girls, in Kuwait adolescents from 87.1 to $106.7 \mathrm{~cm}$ in boys and from 86.7 to $107.0 \mathrm{~cm}$ in girls.

ROC analysis show that the measures sum of 4 skinfolds have the greatest discriminating power in predicting the IOTF obesity for Macedonian adolescents of both sexes. Good descriptive power also shows the variables WHtR and supraspinale SFT. The researches conducted in German (Haas et al.) and Portugal (Sardinha et al., 1999) adolescents showed similar relations. The variable WHtR has shown the best descriptive power to predict abdominal obesity among German boys and girls. Then were followed \%BF, subscapular and sum of 4 skinfolds in boys and WHR, sum of 4 skinfolds and $\% \mathrm{BF}$ in girls (Haas et al.). In older adolescents at the age of 12 to 15 years sum of 4 skinfolds was moving from $0.94 \pm 0.045$ to $0.86 \pm 0.087$ in boys and from $0.94 \pm 0.034$ to $0.95 \pm 0.036$ in girls. The anthropometric measure triceps SFT had the best descriptive predictive power in obesity for boys and girls of this age (Sardinha et al.).

On the basis of the results of ROC analysis and the comparisons presented above, can be concluded that the sum of 4 skinfolds and WHtR should be used as the preferred screening tools. Sum of 4 skinfolds is easy to perform predicts later adult body fatness better than adolescent BMI does. Stomfai et al. (2011) determined that the intra-observer reliability for SFT measures (triceps, subscapular, biceps, suprailiac) was $97.7 \%$, and inter-observer technical error of measurement for skinfold thicknesses was between 0.13 and $0.97 \mathrm{~mm}$. Also, because \%BF can be measured on the basis of SFT measurements these measurements seem to be very useful screening tools along with WHtR measures.

The advantages of this study is that this is one of the first researches realized on Macedonian adolescents. Anthropometric measures were collected by appropriately trained health workers who used the same anatomical measurement points. In addition, the results are representative of today's adolescents, as data on ITM were collected in 2016. The limitations of the study consist in the lack of information on the impact on sexual maturation status on the anthropometric indices, as well as cross-sectional design of the study. Although, references curves are obtained on contemporary data that are likely to be representative of the current situation in Macedonia, the validity of the obtained percentile curves should be confirmed in future research using longitudinal approach. 


\section{CONCLUSIONS}

The level of adiposity of Macedonian adolescents has increased over the past 20 years and has reached the level of developed countries that face an obesity epidemic. The obtained data from the research can be used for logical monitoring of the trends in body fat and obesity among Macedonian adolescents and the spread of anthropometric indicators with other populations. For the proper monitoring of changes in the level of adulthood, it is necessary to repeat such researches every ten years. We conclude that SFT measurements should be used as the preferred screening tool, because they are simple to perform and are better predictors of adult body fatness than adolescent BMI. On the basis of ROC analysis can be concluded that the sum of 4 SFTs and WHtR had the best discriminatory power to predict obesity.

MYRTAJ, N.; MALIQI, A.; GONTAREV, S.; KALAC, R.; GEORGIEV, G. \& BOJADZIEVA, S. B. Antropometría y composición corporal de adolescentes en Macedonia. Int. J. Morphol., 36(4):1398-1406, 2018.

RESUMEN: El objetivo de esta investigación consistió en determinar el nivel de adiposidad y obesidad entre los adolescentes macedonios y comparar los resultados con estudios previos realizados en esta población, así como aquellos realizados en otras poblaciones. La muestra incluyó a 2390 adolescentes de cuatro regiones urbanas diferentes de R. Macedonia con edades comprendidas entre 11 y 18 años (1238 hombres y 1152 mujeres). Se midieron el peso, la altura, la cintura y la circunferencia de la cadera (WC, HC), así como el grosor del pliegue cutáneo tríceps, pantorrilla, subescapular y suprailíaco (SFT). Se calcularon el índice de masa corporal (IMC), la relación cintura-cadera (WHR), la relación cintura-altura (WHtR), la relación de pliegue subcutáneo / tríceps (STR) y el porcentaje de grasa corporal. Se calcularon las prevalencias de sobrepeso y obesidad definidas por la referencia de crecimiento de niños IOTF y se generaron curvas percentiles suavizadas dependientes de la edad y de sexo para las curvas BMI y ROC. Los niños tuvieron valores estadísticamente significativamente más altos de WC, WHR y WHtR en todas las categorías de adultos (excepto WHtR a los 18 años), mayor peso corporal a la edad de 12 a 18 años y peso corporal de 13 a 18 años $(p<0,001)$. El peso, la estatura y el IMC aumentan con la edad tanto en niños como en niñas y disminuyen en las niñas. El nivel de adiposidad de los adolescentes macedonios ha aumentado en los últimos 20 años y ha alcanzado el nivel de los países desarrollados que enfrentan una epidemia de obesidad.

PALABRAS CLAVE: Adolescentes macedonios; Espesor del pliegue cutáneo; Circunferencia de la cintura; Relación cintura-altura; Relación cintura-cadera.

\section{REFERENCES}

Baya Botti, A.; Pérez-Cueto, F. J.; Vasquez Monllor, P. A. \& Kolsteren, P. W. Anthropometry of height, weight, arm, wrist, abdominal circumference and body mass index, for Bolivian adolescents 12 to 18 years: Bolivian adolescent percentile values from the MESA study. Nutr. Hosp., 24(3):304$11,2009$.

de Onis, M.; Blössner, M. \& Borghi, E. Global prevalence and trends of overweight and obesity among preschool children. Am. J. Clin. Nutr., 92(5):1257-64, 2010.

de Onis, M.; Onyango, A. W.; Borghi, E.; Siyam, A.; Nishida, C. \& Siekmann, J. Development of a WHO growth reference for school-aged children and adolescents. Bull. World Health Organ., 85(9):660-7, 2007.

Department of Food and Nutrition Administration. Kuwait Nutritional Surveillance System. Shuwaikh Port, Ministry of Health, 2005.

Dugan, S. A. Exercise for preventing childhood obesity. Phys. Med. Rehabil. Clin. N. Am., 19(2):205-16, 2008.

Galcheva, S. V.; Iotova, V. M.; Yotov, Y. T.; Grozdeva, K. P.; Stratev, V. K. \& Tzaneva, V. I. Waist circumference percentile curves for Bulgarian children and adolescents aged 6-18 years. Int. J. Pediatr. Obes., 4(4):381$8,2009$.

Gharib, N. M. \& Shah, P. Anthropometry and body composition of school children in Bahrain. Ann. Saudi Med., 29(4):258-69, 2009.

Goab, S. \& Chrzanowska, M. Dziecko Krakowskie 2000. Poziom rozwoju biologicznego dzieci i modziezy miasta Krakowa. Kraków, AWF, 2002.

Haas, G. M.; Liepold, E. \& Schwandt, P. Percentile curves for fat patterning in German adolescents. World J. Pediatr., 7(1):16-23, 2011.

Hughes, J.; Li, L.; Chinn, S. \& Rona, R. Trends in growth in England and Scotland, 1972 to 1994. Arch. Dis. Child., 76(3):182-9, 1997.

Lee, J.; Chung, D. S.; Kang, J. H. \& Yu, B. Y. Comparison of visceral fat and liver fat as risk factors of metabolic syndrome. J. Korean Med. Sci., 27(2):184-9, 2012.

Li, C.; Ford, E. S.; Mokdad, A. H. \& Cook, S. Recent trends in waist circumference and waist-height ratio among US children and adolescents. Pediatrics, 118(5):e1390-8, 2006.

Lobstein, T. \& Frelut, M. L. Prevalence of overweight among children in Europe. Obes. Rev., 4(4):195-200, 2003.

Moreno, L. A.; Joyanes, M.; Mesana, M. I.; González-Gross, M.; Gil, C. M.; Sarría, A.; Gutierrez, A.; Garaulet, M.; Perez-Prieto, R.; Bueno, M.; Mar$\cos$, A. \& AVENA Study Group. Harmonization of anthropometric measurements for a multicenter nutrition survey in Spanish adolescents. Nutrition, 19(6):481-6, 2003.

Moreno, L. A.; Mesana, M. I.; González-Gross, M.; Gil, C. M.; Ortega, F. B.; Fleta, J.; Wärnberg, J.; León, J.; Marcos, A. \& Bueno, M. Body fat distribution reference standards in Spanish adolescents: the AVENA Study. Int. J. Obes. (Lond.), 31(12):1798-805, 2007.

Murabito, J. M.; Massaro, J. M.; Clifford, B.; Hoffmann, U. \& Fox, C. S. Depressive symptoms are associated with visceral adiposity in a community-based sample of middle-aged women and men. Obesity (Silver Spring), 21(8):1713-9, 2013.

Musaiger, A. O.; Al-Mannai, M.; Al-Haifi, A. R.; Nabag, F.; Elati, J.; Abahussain, N.; Tayyem, R.; Jalambo, M.; Benhamad, M. \& Al-Mufty, B. Prevalence of overweight and obesity among adolescents in eight Arab countries: comparison between two international standards (ARABEAT2). Nutr. Hosp., 33(5):567, 2016.

Nooyens, A. C.; Koppes, L. L.; Visscher, T. L.; Twisk, J. W.; Kemper, H. C.; Schuit, A. J.; van Mechelen, W. \& Seidell, J. C. Adolescent skinfold thickness is a better predictor of high body fatness in adults than is body mass index: the Amsterdam Growth and Health Longitudinal Study. Am. J. Clin. Nutr., 85(6):1533-9, 2007.

Sardinha, L. B.; Going, S. B.; Teixeira, P. J. \& Lohman, T. G. Receiver operating characteristic analysis of body mass index, triceps skinfold thickness, and arm girth for obesity screening in children and adolescents. Am. J. Clin. Nutr., 70(6):1090-5, 1999. 
MYRTAJ, N.; MALIQI, A.; GONTAREV, S.; KALAC, R.; GEORGIEV, G. \& STOJANOSKA, B. B. Anthropometry and body composition of adolescents in Macedonia. Int. J. Morphol., 36(4):1398-1406, 2018.

Savva, S. C.; Kourides, Y.; Tornaritis, M.; Epiphaniou-Savva, M.; Tafouna, P. \& Kafatos, A. Reference growth curves for cypriot children 6 to 17 years of age. Obes. Res., 9(12):754-62, 2001.

Senbanjo, I. O.; Oshikoya, K. A.; Olutekunbi, O. A. \& Njokanma, O. F. Body fat distribution of children and adolescents in Abeokuta, Southwest Nigeria. Am. J. Phys. Anthropol., 150(4):647-54, 2013

Slaughter, M. H.; Lohman, T. G.; Boileau, R. A.; Horswill, C. A.; Stillman, R. J.; Van Loan, M. D. \& Bemben, D. A. Skinfold equations for estimation of body fatness in children and youth. Hum. Biol., 60(5):70923, 1988.

Stomfai, S.; Ahrens, W.; Bammann, K.; Kovács, E.; Mårild, S.; Michels, N.; Moreno, L. A.; Pohlabeln, H.; Siani, A.; Tornaritis, M.; Veidebaum, T.; Molnár, D. \& IDEFICS Consortium. Intra- and inter-observer reliability in anthropometric measurements in children. Int. J. Obes. (Lond.), 35 Suppl. 1:S45-51, 2011.

Sung, R. Y.; So, H. K.; Choi, K. C.; Nelson, E. A.; Li, A. M.; Yin, J. A.; Kwok, C. W.; Ng, P. C. \& Fok, T. F. Waist circumference and waist-toheight ratio of Hong Kong Chinese children. B. M. C. Public Health, 8:324, 2008.

Taylor, R. W.; Jones, I. E.; Williams, S. M. \& Goulding, A. Evaluation of waist circumference, waist-to-hip ratio, and the conicity index as screening tools for high trunk fat mass, as measured by dual-energy Xray absorptiometry, in children aged 3-19 y. Am. J. Clin. Nutr., 72(2):490-5, 2000.

\author{
Correspondence to: \\ Seryozha Gontarev \\ University "Ss. Cyril and Methodius" \\ Faculty of Physical Education \\ Sport and Health \\ Skopje \\ REPUBLIC OF MACEDONIA
}

Email:gontarevserjoza@gmail.com

Received: 17-02-2018

Accepted: 14-06-2018 